\title{
THE ROLE OF PRIVATE CREDIT IN HEMISPHERIC TRADE
}

\author{
StgGrRird StrRn*
}

Prior to the first World War, private short-term credit from European nations played a leading part in the financing of Latin American trade. This credit was largely provided by special banks founded by Europeans for the development of their foreign trade in the Western Hemisphere. British banks were first established in Argentina in the early sixties of the nineteenth century. German banks followed them some twenty years later. Still later, branches of banks of other nationalities were established, including Canadian, Dutch, French, Swiss, Italian, Belgian, Spanish and Portuguese. Private credit at long term for the development of capital projects was granted to a great extent through the issuance of bonds in the London money market, though by the turn of the century continental financial centers, principally Paris, Amsterdam and Brussels, had begun to challenge London's predominant position in this field.

Although we had maintained trade relationships with Latin American countries for many years, private credit agencies in the United States first became interested in Latin America around the time of the first World War. During and after that war, both short- and long-term credit was extended in greater and greater volume to our neighboring countries to the south. The crisis of I92I and later the depression of the I930's interfered for a time with this flow, but, since the outbreak of the present war, the amounts of short-term credit used by our southern neighbors have been of increasing importance as measured against the aggregate private credit extended from the United States to the entire world.

\section{Forms of Private Credit}

Private credit in hemispheric trade is extended by local commercial banks, branches of foreign banks, by central banks, by commercial banks of the United States, and by American manufacturers, exporters and traders. It is employed to

* Vice President, The Chase National Bank of the City of New York, Vice President and Director, The Chase Bank, New York, since 1930. Member, Governing Council, National Foreign Trade Council; Member, Inter-American Panel of Arbitrators, American Arbitration Association; member of numerous other organizations in the field of foreign trade and relations. Author of The Foreign Exchange Problem (192I); Fourtcen Years of European Investments (1929); and many articles and addresses on foreign trade, investment, and exchange. 
finance exports to and imports from Latin America, as well as production and distribution of raw materials and other commodities and also capital projects. There are, in general, three categories: short-, medium-, and long-term.

Short-term credit embraces as a rule a period of from three to six months in the financing of manufactured products, and up to nine months or even one year in the case of agricultural products. Medium-term generally ranges in length from one to five years. Long-term is usually applied either to public bond issues running for longer than five years or to direct investments.

Short-term commitments by commercial banks in the United States to Latin American borrowers usually take the form known in business parlance as "credit lines." These are maximum amounts up to which the borrower may use the facility of the lending bank for the specific purpose for which the credit was granted. Shortterm credit lines are of three principal types: mail credits and overdraft lines, sight commercial letter of credit lines, and acceptance lines.

By a mail credit or overdraft line, an amount is established up to which the borrower may overdraw his account on the books of the lending bank. Overdrafts arise mainly through cable or mail payment orders or through checks honored by the borrower's bank prior to its receipt of remittances sent by the borrower. Overdrafts for longer periods may also be arranged as, for example, during a crop-moving period. Since it is used to finance seasonal shipments, this type of overdraft may run for several months.

Sight commercial letter of credit lines fix those limits up to which a commercial bank is willing to establish irrevocable letters of credit for a client under which sight drafts will be drawn by shippers and paid by the drawee bank upon presentation with the necessary accompanying documents. When the American bank substitutes its own responsibility for that of the Latin American obligor, the credit is said to be "confirmed."

Acceptance lines are of two kinds: the first fixes the limits up to which a commercial bank is willing to establish letters of credit under which time drafts may be drawn by shippers. Such drafts usually have tenors up to 90 days and, upon presentation with the proper documents, are accepted by the bank opening the relative letter of credit. Lines of this nature are usually extended by United States banks to. their correspondent banks in Latin America through which accommodation in turn may be made available to local Latin American buyers. The second of these consists of those limits up to which various banks in Latin America and certain other countries may draw on United States banks to provide "dollar exchange," as provided by the Federal Reserve Act.

The creation of an acceptance market in the United States after the passage of the Federal Reserve Act in I9I3 enabled United States banks to compete in this field with the established European money markets and, at the same time, redounded to the benefit of Latin American users of credit. There are now about 33 banks in New 
York and 77 banks in other commercial and financial centers of the United States engaged in foreign banking. The Federal Reserve Act also provided that national banking associations meeting certain requirements could establish branches in foreign countries for the furtherance of the foreign commerce of this country, and several American institutions took advantage of these provisions.

Long before the opening of foreign branches, direct and active correspondent relationships were established with the head offices and branches of the more important commercial banks operating in Latin America. While the principal task of the Latin American banks in the past was to finance agricultural credit needs, the local banks also became important factors in financing domestic industry and commerce in those countries where local industries developed. Later on, these banks turned their attention to foreign trade, and, with the gradual cementing of their relations with the United States, an increasing volume of foreign trade financing has been handled through their intermediaries in this country. Most of these banks enjoy experienced management, and the increase in their resources has paralleled the growth in the volume of their business.

In their efforts to cultivate close relationships with local banks, American institutions have had the willing and sympathetic cooperation of the central banks. These have been most helpful in the direction of improving local credit conditions, in stabilizing interest rates, in supporting foreign-exchange rates, in offering in many instances re-discount facilities to local banks, and in adding generally to the security of American banks extending credit to local debtors.

Transactions in hemispheric trade may also be financed by American commercial banks on the basis of the credit standing of the United States exporter. For example, an exporter may ship goods and draw a sight or time draft directly on the Latin American importer. In this instance, the bank in the United States relies upon the American exporter to make good if the draft is not paid. Of course, the drawee's name and the character of the underlying merchandise may have a definite bearing on the bank's readiness to make such advances. An important proportion of export shipments from the United States is financed by the exporters themselves on open account or draft basis. In such cases, the banks may still act as collection agents.

For a number of years, medium-term private credit has been extended by commercial banks in Europe to finance exports to Latin America. These extensions have usually been made possible by government-sponsored guarantee schemes advantageous to the exporters. Political, foreign-exchange, and other risks have in effect been insured by the exporters' governments. Similarly, in the case of the United States, medium-term credit advances have often been made by commercial banks with the cooperation and backing of the Export-Import Bank in connection with the export of needed capital goods such as railway equipment, trucks, tractors, etc., to Latin America.

Long-term private credits in this hemisphere have usually taken the form of 
portfolio investments or direct investments. With comparatively few exceptions, the former have consisted of the publicly issued bonds of governments and governmental agencies. Their proceeds have been intended for the financing of capital projects, such as highways, railroads and equipment, and other improvements designed to increase the productivity or accessibility to markets of the borrowing country. However, this form of credit has also been used, unfortunately, too often for economically unproductive purposes. It might be mentioned that, in contrast to the policy generally followed by European investment bankers, the underwriters of Latin American securities issued here seldom required by contract that the dollar proceeds should be expended solely in the United States. Long-term credit in the form of direct investment, on the other hand, has almost exclusively been used for purposes that were economically productive such as the establishment of plantations, sugar centrals, public utilities, railroad and other transportation systems, automobile assembly plants, meat-packing plants, oil wells, refineries, etc.

In recent years, because of political risks and trade and exchange restrictions, private capital has been generally available only for short-term business transactions and for direct investment. Because of this fact, the United States Government, through various agencies, has recently made longer term advances to Latin American republics not only to assist them in obtaining needed capital goods but also in the interest of defense objectives.

\section{Credit and Exchange Factors}

The major factors to be considered in determining whether private credits should be extended are not only the credit standing of the individual borrower but also the exchange situation within his country, its gold reserves, its past record as a debtor nation, its balance of payments, as well as its general economic and political situation. It is generally understood in private credit relationships that the borrower should have both willingness and ability to repay debts incurred.

Where a prospective customer's standing is not sufficiently well known to an exporter to enable him to ship on open account or on a straight draft basis, a commercial bank letter of credit will be requested. This procedure is also followed with shipments of certain commodities, such as coffee, cocoa, hides, wool, rubber, etc., as required by trade usage regardless of the buyer's credit standing, as well as when the amount involved is unduly large or the product has to be specially manufactured.

In addition to credit standing and collateral, the seller or lender must consider the foreign-exchange situation within the borrower's country. This is of importance in view of the exchange and import controls currently in effect in so many countries and adding so greatly to the uncertainties of the prompt return of the proceeds of exports. A Latin American borrower may be perfectly able to raise a sufficient amount in his own currency to pay back a foreign debt. When, however, he seeks foreign exchange he may find that the governmental bureau or office of exchange 
control declines to make it available until such time as the balance of payments has improved.

Governmental exchange control is used to insure that export proceeds are applied to the essential needs of (a) government purchases; (b) imports; (c) travel and study requirements; and (d) debt service, usually in about that order. The most important characteristic is the control of the quantity and distribution of imports. Various rates of exchange for all these types of transactions are often established to achieve a desired direction of trade as well as a profit for the controlling government agency. Conditions may be unsettled for a number of reasons, such as the loss of normal markets due to war or a decline in the prices of major export commodities. Then, too, a country may have entered into bilateral trade agreements with certain countries which favor those countries in the distribution of its available exchange to the detriment of all other countries.

The question has been asked whether long-term investors and short-term creditors compete for exchange. Of course, exchange controls do not always provide for equality of treatment. Policies are governed by local conditions and the conception of the authorities of their best economic interests. As a rule, the foreign holder of government bonds receives least favorable consideration, although in some instances payment of bond interest and the building up of sinking funds is provided out of special sources of income.

Inasmuch as exchange controls usually are accompanied by license or other restrictions governing exports or imports, the "red tape" encountered in foreign trade with countries with such controls tends to be increased considerably. There has necessarily been a tendency to reduce private unsecured short-term credits to borrowers in countries where abrupt changes in such regulations are likely.

Under a proclamation by the President of the United States of America dated July I7, x94I "The Proclaimed List of Certain Blocked Nationals" was promulgated. This list contains the names of those companies, firms and individuals, having or being suspected of having Axis ties, with whom shippers and banks in the United States are prohibited from trading without a license. Under these conditions, the extension of private credit in Latin America involves the added risk that the proposed buyer, at some future date and through some action not under the creditor's control, might be placed on this list. In such a case, the debtor's assets in the United States would become blocked and transactions with him forbidden, which of course might make the liquidation of a debt difficult or impossible.

The control of exports and the restrictions imposed on shipments to blocked or listed nationals have imposed additional duties upon the banks in connection with their credits in Latin America which, in the national interest, they are discharging to the fullest possible extent. Administering the machinery has of course caused inconveniences to all concerned-and especially to exporters and importers. 
In connection with the export of products affected by priority or allocation requirements or requiring special manufacture, there has been a tendency lately for some United States exporters to require cash or the establishment by Latin American buyers of prime American bank irrevocable confirmed letters of credit payable against certificates of manufacture at the maker's plant, instead of against the usual shipping documents. Moreover, in the hope of securing prompter shipments than might otherwise be effected, some Latin American importers have been establishing similar letters of credit to cover the purchase of various items such as chemicals, machinery, tools, and other steel products.

Many banks in the United States have also in certain instances required cash before opening credits. When, simultaneously with the opening of the letters of credit the Latin American buyer has to deposit cash with his own bank and the latter in turn has to provide dollars with its New York correspondent, the funds of the Latin American buyer or his local bank may be tied up for as much as six months or even a year while he awaits the manufacture and delivery of his merchandise, whereas, in ordinary times, the buyer should be able to turn over his capital three or four times a year. In an effort to alleviate this situation, the Export-Import Bank has offered to arrange special lines of credit through central banks in Latin America, in connection with which the Bank will assume certain risks in the production and export of essential products which commercial banks are not now in a position to carry. These special lines will be handled by commercial banks in the United States under the instructions and responsibility of the Export-Import Bank and are to be used "in exceptional cases where neither the importer nor the exporter is agreeable, in the face of an increasing war defense economy and summary regulations, to assume the risks incidental to the delivery of goods from plants to ports of destination."

It is still too early to foresee the ultimate effect of these special credit lines on hemispheric trade. No limit seems to have been officially mentioned for the total amount of credit to be made available to Latin American buyers.

\section{Volume of Short-term Credits}

There are no figures available indicating the total amount of private credit extended in hemispheric trade. However, the amount of credit required for financing present-day Latin American exports has been estimated at about $\$ 500$ million a year. Some indication of the amount of banking credit used in Latin American trade is presented in the table below which shows for the years 1935 to $194 \mathrm{x}$ the total volume of foreign short-term liabilities and assets of all banks in the United States and also the percentages which the Latin American assets and liabilities bear to the data for the entire world. 
Short-term Liabilities and Assets of Banks and Bankers in the United States Latin America Compared with the Entire World*

Liabilities
(Millions of U.

Entire

World

Jan. $2, x 935 \ldots \ldots . \quad 597.0$

Jan. $x, 1936 \ldots \ldots$. 1200.2

Dec. $30,1936 \ldots \ldots$ I .... I 49 . 6

Dec. 29, $1937 \ldots \ldots . . \ldots 729.6$

Jan. $4,1939 \ldots \ldots$. 1996.6

Jan. $3,1940 \ldots \ldots 3057.0$

Jan. $x, 194 x \ldots \ldots 37^{85.2}$

Apr. 2, 1941...... 3775.0

July 2 , I941...... $3^{819.5}$

July $30,1941 \ldots \ldots .3767 .6$
Latin Latin America
America of Entire World

I22.8 20.6

$156.3 \quad 13.0$

$263.9 \quad 17.7$

$280.9 \quad 16.2$

248.5

336.0

$447 \cdot 3$

470.2

492.8

474.6
Assets

(Millions of U. S. $\$$ ) \%

Entire

World

II 39.9

778.6

672.6

655.0

594.0

508.7

384.0

391.7

340.5

355.6
Latin - Latin America

America of Entire World

$\mathrm{r74.6} \quad \mathrm{I5} \cdot 3$

$\mathrm{I} 54.5 \quad \mathrm{Ig} .8$

I4I.I 21.0

II 4.4 I7.5

99. $\quad x 6.7$

II3.3 22.3

$122.7 \quad 32.0$

I2I.6 $\quad 31.0$

II3.9 33.5

I $6.8 \quad 32.8$

July 30 , I 941 as

percentage of

$\begin{array}{lllll}\text { Jan. } 2, \text { I } 935 \ldots . . .6 & 631.1 \% & 386.5 \% & 31.2 \% & 66.9 \%\end{array}$

Sources: Federal Reserve Bulletin for data from January 2, 1935 through January 4, 1939; Bulletin of the U. S. Treasury Department for data from January 3,1940 .

On July 30, I94I, the geographical distribution of the above liabilities and assets in Latin America was as follows:

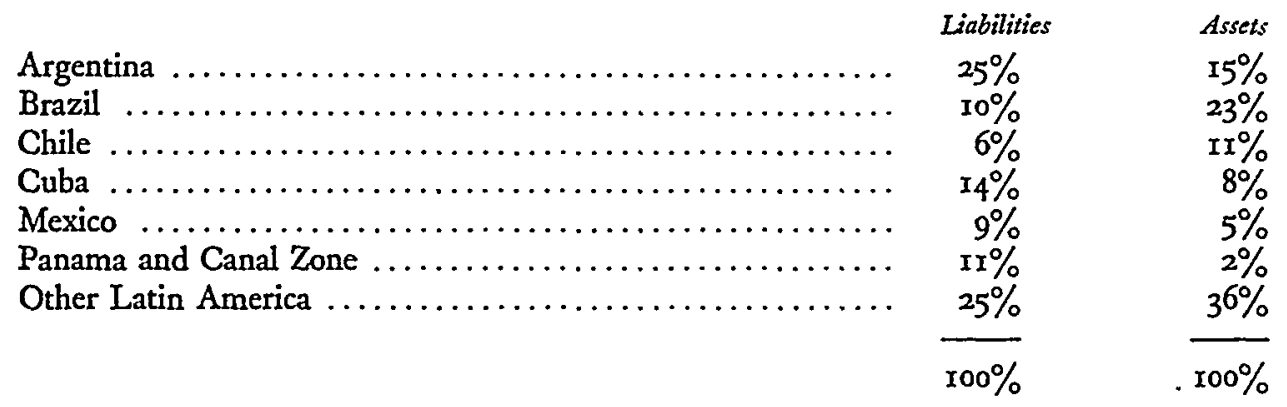

The liabilities consist almost entirely of deposits in current account. The assets consist principally of claims against foreigners. Some are payable in foreign currencies, but these have rarely exceeded $5 \%$ of the total. The preponderance is payable in United States dollars, and the largest single types have been loans to foreign banks and acceptances made for foreign account.

It will be seen that, from the beginning of 1935 through the middle of the year I94I, the liabilities for the entire world increased more than six times over, due to the flowing of "hot money," refugee and other funds to the United States. During this same period Latin American liabilities declined from $20.6 \%$ to $12.9 \%$ of the world totals and increased fourfold in absolute amount. A part of this influx from Latin America consisted of European funds which migrated indirectly to the United States. On the other hand, the increasing relative importance of credit extensions to Latin American debtors by banks and bankers in the United States during the same 
period is significant. Loans, acceptances, etc., to Latin America rose from $15.3 \%$ to $33.5 \%$ of the world totals.

Between early 1939, prior to the outbreak of present hostilities, and the end of 1940, there was an increase of about $20 \%$ in the total volume of short-term Latin American assets of banks and bankers in the United States. Undoubtedly, a large part of this increase can be attributed to increased Latin American trade, although it has not been nearly so great proportionately as the increase in that trade. This is due in part to the fact that, as already pointed out, a substantial share of American exports to Latin America is financed by the exporters' capital funds or credits. Furthermore, practically all imports are paid for either in cash or by means of letters of credit opened by United States buyers in favor of Latin American sellers.

While the total amount of credit extended by American banks to Latin America may be considered modest, it should be emphasized that the borrowers in many cases have not used in their entirety the lines of credit placed at their disposal. There is no doubt that North American banks have been criticized in the past for not being generous enough in the amounts of credits extended, as well as for their disinclination to grant credit for as long periods and sometimes at as low rates as those of their competitors of other nationalities. The experiences of the early and the late I920's, when several American foreign-trade banks formed to do business in Latin America and the Far East came to grief, have naturally been a restraining factor. Since then, American commercial banks have gained much experience, and they show a genuine desire to meet the legitimate needs of their foreign customers in the most liberal manner consistent with sound banking principles.

In the same spirit commercial banks have welcomed the resourceful cooperation of the Office of the Coordinator of Inter-American Affairs, of which Nelson A. Rockefeller is the guiding spirit, which has taken an active interest in promoting adequate credit facilities for increased commerce. It is also recognized that the Export-Import Bank, far from competing with the commercial banks, has performed a role in the extension of credit in Latin America which the commercial banks admittedly have not been able to play because they are governed by Federal Reserve regulations as to the character of the transactions which they may handle.

Commercial banks in the United States have cooperated in financing numerous industries and business enterprises in Latin America, thus creating additional employment opportunities and adding to the economic wealth of those communities. This cooperation has taken the form of credits granted to cotton houses either unsecured or against pledge of the raw material for the purchase of the local production; for the financing of shipments of metal and minerals from the mine to the ocean port; and to contractors engaged on government projects. Other credits include those extended for crop financing in the sugar- and some of the coffee-producing countries, for the production of sugar by centrals, and for the financing of importations of machinery and equipment. The credits have been distributed with care and 
to responsible debtors and were extended on terms more favorable than those governing local transactions in the countries concerned.

Short-term credits in Latin America are generally being liquidated promptly. There has been a noticeable improvement in this particular since the readjustment of these countries to war conditions. The Foreign Credit Interchange Bureau of the National Association of Credit Men report on the basis of a survey carried out among their members that the average yearly credit losses of American exporters in Latin American trade are relatively small.

\section{Long-term Credits}

Latin American government bonds began to attract the interest of United States investors during the first World War. A comparatively small volume of such issues was floated in the United States between Ig0o and I9I4, mainly by Mexico and Cuba, rising between I9I4 and I9I9, to \$I00 million. After a lull during the crisis of the early '2os, lending operatings were resumed, and during the next decade the aggregate of Latin American dollar bonds, including issues for the purpose of refunding loans originally placed in Europe, rose to well over $\$ 2$ billion.

About r930, when the depression set in, new investment of long-term private capital in Latin American bonds ceased and defaults on many issues began. At the end of 1940, outstanding Latin American dollar bonds are estimated to have amounted to $\$, 508$ million, of which it has been variously estimated that upwards of $\$$ I billion face amount are in the United States. Of the total sum $74 \%$ were as of that date in total or partial default.

The reasons for Latin American defaults have been various. Some loans may have been unwisely granted or may have been unwisely requested on the basis of overoptimistic expectations. But all such negative factors might have become mere incidents in a generally favorable economic situation if Latin America's export trade had continued to flourish. In the I920's, heavy Latin American imports were paid for by borrowing abroad and by large exports of commodities with the result that Latin American countries became more and more dependent upon the international commodity and money markets. When the inflow of long-term credit stopped and when the world prices of most major raw materials exported by Latin America fell, in some cases to less than half their I929 levels, the income of the Latin American nations suffered severely. Lacking sufficient foreign exchange from their exports and lacking new loans to help pay old debts, defaults seemed to them in many cases the only way out.

On the other hand, there was undoubtedly, in some cases, unwillingness as well as inability to pay. If a country makes no effort to adjust its debt and uses free funds to repatriate bonds selling, because of default, at a fraction of their par value, then the debtor government may perhaps be regarded as unwilling to pay. Thus, a distinction may be made between default for financial and fiscal reasons, and default 
which borders on repudiation of the major part of the debt, even though the latter may be caused by considerations of a social or political nature.

In earlier years, the United States was more inclined to support its citizens' rights as creditors. After the inauguration of the Good Neighbor policies, these earlier methods were abandoned, for, besides being resented throughout Latin America, they left unsolved problems of long-term economic relations. Even where debtor nations have had favorable export balances with the United States which might have eased the debt collection problem, the Administration has steadfastly avoided entering into bilateral agreements.

Direct investments in Latin America by corporations and individuals of the United States at the end of I939 were said to amount to $\$ 2,963$ million, or between two and three times the amount of Latin American dollar bonds in the portfolios of investors in this country. Enterprises for the extraction and export of tropical and mineral products from mines, oil wells and plantations, account for the major part of the United States investment, although some $\$ \mathrm{r}, 300$ million have been supplied by United States investors for "non-export" enterprises, such as public utilities, railroads, banks, tire factories, automobile and agricultural machinery assembly plants, sales organizations, water and air transport, cables and telephone lines.

Over the past two decades, American capital has flowed into the main Latin American countries to develop domestic industries, such as those above mentioned, and to supply management and technical skill through the establishment of subsidiaries and branches of American enterprises. A great many American concerns have participated in the effort, and it is due in no small degree to their effective initiative that the policy of the good neighbor in Latin America has produced such encouraging results. ${ }^{1}$

The larger part of the direct investments in Latin America which have been made by companies or individuals from the United States have been made in those countries which accounted for the lion's share of Latin America's exports to us. Cuba seems to be first on the list, with Chile, Mexico, Argentina, Brazil, Venezuela, and Colombia following in the order named. The United States direct investments in Latin America were estimated in 1936 to be distributed by areas as follows: Caribbean Area (including Mexico, Colombia and Venezuela), 59\%; West Coast (Chile, Peru, Bolivia, Ecuador), 21\%; East Coast (Argentina, Uruguay, Paraguay), $13 \%$; Brazil, $7 \%$.

\footnotetext{
${ }^{1}$ The following is a partial list of American concerns having plant investment or inventories in Latin America:

American Coffee Co.

American Foreign Power Co.

Anaconda Copper Co.

Anderson Clayton \& Co.

Armco International Corp.

Armour \& Co.

Cerro de Pasco Copper Co.

E. I. duPont de Nemours \& Co.

Ford Motor Company

Goodyear Tire \& Rubber Co.

W. R. Grace \& Co. International Business Machines Co.

International Harvester Co.

International Tclegraph \& Tclephone Co.

Johnson \& Johnson

Kennecott Copper Corp.

Lone Star Cement Co. Singer Sewing Machine Co. Socony Vacuum Oil Co. Standard Oil Co. of N. J. Swift \& Company Texas Co. United Fruit Co. Wessel Duval \& Co. Wilson \& Co.
}

General Motors Corp. 


\section{Private Credit in the Post-war Period}

The pattern of European and world economic organization which will be set up in the event of a Nazi victory has been made clear. Germany would be the industrial and financial center and would determine the kind and degree of territorial specialization that would be permitted for each country. Trade would generally flow to and from the center except such as would be allowed to be cleared by exchanges of balances at the center. While the present forms of banking, investment, public finance and production might be preserved, effective control would be in the hands of the State.

But if the democratic nations are victorious, it is not to be assumed that there would be a reversion to laissez faire as it was known in the nineteenth century. Rather, the attainment of a closer and more effective cooperation among nations is a necessity imposed by modern evolution of transport and communication. Such a development seems to be contemplated by Article Fourth of the Atlantic Charter of August, 194I, which reads: "They will endeavor, with due respect for their existing obligations, to further the enjoyment by all states, great or small, victor or vanquished, of access, on equal terms, to the trade and to the raw materials of the world which are needed for their economic prosperity."

The restoration of freer international trade and finance should go a long way in the post-war period towards alleviating the production problems of the nonbelligerent areas and the reconstruction problems of the belligerent areas. Nevertheless, the extension of private long-term credit in the post-war period will probably have to be coordinated, so that loans will be extended only after due consideration is given the balances of trade and payments of the borrowing country.

In the Latin American countries, as a basis for the satisfactory stabilization of production and exchanges, it would be desirable for the central banks or exchange control offices to carry further their studies of national balances of trade and payments. Although undoubtedly these agencies have an intimate knowledge of the main components of their balance of payments, there is still a great dearth of such information with regard to the Central and South American republics, while in the United States the results of careful studies regarding our international balance of payments are publicly available.

It would be desirable and would greatly enhance the credit of the various countries if steps were taken to obtain more complete statements of both the permanent and the fluctuating debit and credit factors, the nature and the amount of receipts and disbursements in foreign currencies based on the trade balance, foreign investments, service of foreign debt, tourist travel, freight insurance payments, current government expenses abroad, short-term loans falling due and payments to nonresident investors in local industries.

On the whole, it would appear that Latin America has at present a source of dollars in its net visible export balance. In the matter of service items, Latin America has been a debtor over a long period of years. Remittances on account of earnings 
of American corporations in Latin America are of course variable. On the other hand, the Latin American republics undoubtedly enjoy a balance in their favor from tourist expenditures. The net unfavorable balance of payment for Latin America has in part been offset in the past by shipments of gold and silver and new credits or loans from either private or government sources in the United States.

No examination of the influences affecting the future extension of private credit in Latin America would be complete without considering the prospects for gradual increase in their gold reserves which are now estimated at $\$ 485$ million. Although these countries may be less dependent on gold exports to balance their international accounts during the immediate future, mention should be made of the production of gold in Brazil, Chile, Colombia, Mexico and Peru-to note only a few of the countries-valued in 1940 at upwards of \$103 million. Undoubtedly, with increased output, some of the gold-producing countries will in time be able to build up further their internal gold reserves.

The suggestion has been made that it might be possible to link the Latin American currencies to the dollar. Before such a desirable objective might be consummated, it would be necessary to solve certain budgetary and economic problems and to rehabilitate the fiscal policies of certain countries. To create the stability necessary for such a plan, it would be imperative to accumulate much larger reserves of gold and dollar exchange than are now available so that, in the event of heavy deficits in the balance of payments, the debtor nations would have sufficient reserves to protect their currencies. Yet, without entering into the question of the purchases by our government of strategic and critical materials, considered elsewhere in this issue, it should be pointed out that the accumulation of dollar exchange by the various countries in which orders for purchases have been placed has contributed in no small degree to the improvement of their financial condition.

Some Latin American countries have thus been furnished with an opportunity to reduce their foreign debts and build up their gold and foreign exchange reserves during this war. Furthermore, the central and commercial banks of certain countries, like our own banks, have become refuges for foreign capital. This has been reflected in rising dollar balances of the Latin American banks in the United States. This improved financial position has, in turn, facilitated the financing of current business by means of these increased dollar balances and has temporarily reduced the demand for private credit. It is possible also, because of favorable trade balances resulting in larger deposits and earmarked funds in the United States, that, when the post-war readjustment comes, certain Latin American countries will have available important reserves which will make it easier for them to maintain the stability of their currencies. This should reduce somewhat their former dependence on foreign credits.

The further extension of private credit, both short- and long-term, in Latin America depends not only on financial and economic factors but also on the maintenance of stable internal political conditions and upon the elimination of discriminatory legislation affecting foreign capital. Exchange controls which result in 
the blocking of dividend and interest remittances to foreigners and well-meant but sometimes excessive social reform legislation, such as restrictive labor laws and the nationalization and even expropriation of industries, are not a basis for confidence and for the extension of private credit. Moreover, there is a need for adjustment of the long-term debts now in default.

It must be borne in mind that in a few countries there are still blocked important amounts of American funds arising from interest payments and profits as well as some proceeds of exports, for which temporarily no exchange is available. It is evident that the existence of frozen investments or local overdue loans is an obstacle to the re-establishment of credit from private sources. Moreover, it is doubtful that certain of the countries of Latin America can retain their places as important suppliers of the United States in the after-war period, when the demand here may decline. Hence there will probably be a necessity for these countries to husband their dollar resources and to continue foreign exchange control until conditions have been stabilized. The fostering of new industries and handicrafts likely to find a ready market not only at home but in other countries, as well as the encouragement of capital imports and long-term investment, would seem the soundest economic policy for the Latin American nations which wish to prepare now for the new era likely to face them after the close of the war.

The Latin American countries find themselves in the same position in which the United States was around the turn of the last century. Then we were fortunate in enjoying substantial private short-term and long-term credit in England. The countries of Latin America will look to us to carry them through the post-war period and help to finance their development by giving credit and financial aid to their commerce on the same generous basis as the English bankers did for us two generations ago. If wisely granted and carefully supervised, private capital loans and credits extended in the southern part of this hemisphere will undoubtedly be as profitable materially and politically as the British loans were to us, although the evolution in Latin America may be slower than it was here.

The prospects for private credit in hemispheric trade in the post-war period also depend to a great extent upon the policies of the United States. If this country should continue its present multilateral trade policy so that trade restrictions would be reduced, there would no doubt be a greater volume of imports, and outstanding foreign loans could be repaid in goods.

After the war, the empty warehouses of continental Europe will constitute a great potential market for much of the foodstuffs and raw materials that both Latin America and the United States have to sell. The great problem will be to translate actual need into effective demand, i.e., purchasing power. Temporary loans will certainly be necessary, although the chaotic conditions which have followed most wars would suggest that the business aspect of these loans may have to be subordinated.

Of course, in the post-war period the overliberal loan policy of the 1920's will have to be ayoided, for excesses in the granting of credits are as harmful as exag- 
gerated conservatism. Any long-term lending of the future must take into account the growing nationalism in Latin America. Therefore, it would seem to be important to have the participation of local capital and management, to secure not only the good will of local business and labor, but also the benevolent attitude of the respective governments and municipalities. In the words of the Minister of Finance of Colombia, "Capital must come into the country to join our enterprises, to work under the protection of our laws, to incorporate itself definitely into our activities." Further, United States capital might be sent to Latin America to help in creating factories to make for local consumption many types of cheaper goods which were formerly obtained elsewhere and which would not compete with products which the United States has been exporting to Latin America.

Undoubtedly, as time goes on and the economic and financial structure of the American republics is further strengthened, and as the danger of periodic crises is lessened, the role of the dispensers of private credit may again become more important, and, to a certain degree at least, they will be able to take over the functions which are now, with great discernment and constructive judgment, exercised by the Export-Import Bank and the Reconstruction Finance Corporation. There, of course, are certain activities outside the sphere of commercial banks which should be financed with the capital of private stockholders, such as those concerned with the construction of public highways, railroads, dock works, mills and factories. Credits secured by brick and mortar are usually outside the realm of the principal commercial banks. Moreover, it is not the function of private corporations to grant loans to prevent price collapses in exporting countries. A government may find it politically expedient to provide funds for purchasing or loaning against surpluses, or building public works, while the private investor or creditor as a rule will look first to the safety of capital.

Much post-war financing, it seems today, will of necessity have to be long-term in character, and, in the beginning, at least, may have to consist of credits extended by the United States Government to foreign governments rather than of private credit in the form of publicly issued securities. In this respect, we in this country must make allowance for the damage inflicted on the economies of some Latin American republics during the war by the closing of their markets and the consequent accumulation of unsold commodities. At the war's close, all financial and trading problems must be examined in an unselfish way, and we must do all that our financial and shipping position will allow us in order to satisfy the most urgent requirements of our southern neighbors.

In the domain of American public policy, it is to be hoped that the efforts of all interested governmental authorities will be enlisted more than ever before to support American institutions and traders engaged in international banking and commerce. War has emphasized the importance of the United States in world affairs. The reputation and leadership of London as the international banking and financial center is in no small degree due to the standing and credit enjoyed by the sterling bill of exchange and the London letter of credit. Notwithstanding initial mistakes which, 
considering conditions then prevailing, are in some degree pardonable, American banks in the international field have succeeded during the past two decades in taking an honorable place alongside the great banks of the City of London. If we wish to strengthen our trade ties in Latin America to the detriment of the totalitarian powers, as a first requisite we should enhance and not jeopardize the confidence hitherto enjoyed by that traditionally unquestioned tool of international commercethe letter of credit.

\section{Conclusion}

Looking ahead to what will be required of us and our Latin American friends at the close of this war, and summarizing what has been said above, the following policies appear to be desirable as a sound and constructive program for the future:

For Latin American nations,

a) maintenance of "favorable" trade balances,

b) increasing development of national resources,

c) elimination of exchange controls and restrictions,

d) placing budgets upon a firm foundation and adjustment of foreign debts on a secure basis,

e) diversification of production and establishment of appropriate new local industries,

f) maintenance of stable internal political conditions,

g) adoption of sound economic and financial policies that will protect past investments and encourage the inflow of further American private capital and credit to collaborate with local interests, on the basis of equal treatment for all.

For the United States,

a) acceptance of the role and recognition of the obligations of a creditor nation,

b) encouragement of an "unfavorable" balance of trade through an excess of imports,

c) encouragement of the outflow of gold,

d) aiding the Latin American republics in the sound development of their natural resources,

e) reduction of governmental control unless such is necessary for defense,

f) abandonment as soon as possible of government competition with private business,

g) the continued promotion of friendship and solidarity among the peoples of the Western Hemisphere by policies tending to strengthen the existing ties between the Latin American nations and ourselves and the development of the natural endowments with which those nations have been so abundantly supplied. 